\title{
Molecular characteristic on intra-species of Metroxylon sagu from Papua, Indonesia by nad2 and matK genes
}

\author{
BARAHIMA ABBAS ${ }^{1,2, v}$, NOUKE LENDA MAWIKERE ${ }^{1,2}$, IHWAN TJOLLI ${ }^{1}$, MUHAMMAD ARSYAD \\ MUNARTI ${ }^{4}$ \\ ${ }^{1}$ Faculty of Agriculture, Universitas Papua. Jl. Gunung Salju, Manokwari 98314, West Papua, Indonesia. ^email: b.abbas@unipa.ac.id \\ ${ }^{2}$ Post Graduate Program, Universitas Papua. Jl. Gunung Salju, Amban, Manokwari 98314, West Papua, Indonesia \\ ${ }^{3}$ Doctoral Student Post Graduate Program, Universitas Papua Jl. Gunung Salju, Amban, Manokwari 98314, West Papua, Indonesia \\ ${ }^{4}$ Faculty of Teacher Training and Education Science, Universitas Pakuan. Jl. Pakuan Bogor 16143, West Java, Indonesia
}

Manuscript received: 20 October 2021. Revision accepted: 10 November 2021.

\begin{abstract}
Abbas B, Mawikere NL, Tjolli I, Arsyad M, Munarti. 2021. Molecular characteristic on intra-species of Metroxylon sagu from Papua, Indonesia by nad2 and matK genes. Biodiversitas 22: 5302-5310. Sago palm (Metroxylon sagu Rottb.) is a palm that is capable accumulated a lot of starch for food in the trunk. The molecular characterization of sago palm is very important as identities of biological existence in the certain areas. This study aimed to reveal molecular characteristic on intra-species of $M$. sagu from Papua based on NADH dehydrogenase subunit 2 ( $\operatorname{mad} 2)$ gene and maturase K (matK) gene. 15 accessions were used in this study. Sequences of $n a d 2$ gene on some accessions of $M$. sagu were shown that no differences. The nad 2 gene on some accessions of $M$. sagu was inferred only one haplotype and the matK gene were inferred two haplotypes. The highest frequencies of the nucleotide in both $n a d 2$ and $m a t \mathrm{~K}$ gene were calculated thymine (T). The amino acid leucine was the most common, accounting for $11.44 \%$ of haplotype- 1 and $11.50 \%$ of haplotype-2. The amino acids alanine, cysteine, and methionine have the lowest rates, with $1.99 \%$ for haplotype- 1 and $2.00 \%$ for haplotype-2. The evolutionary relationships were shown no mutation rates occur in the nad2 gene and lower mutation rates occur in the matK gene on M. sagu. Based on the genotype-2 (Sagu01, Sagu02, Sagu08, Sagu12, and Sagu15) is proposed to be new variety.
\end{abstract}

Keywords: Chloroplast, matK gene, Metroxylon sagu, mitochondrial, nad2 gene

\section{INTRODUCTION}

Sago palm (Metroxylon sagu Rottb.) is a palm that is capable accumulated a lot of starch in the trunk. Metroxylon sagu is one of the well-known palm species producing sago which is the main food staple for certain tribes in the eastern part of Indonesia. Abbas (2015) and Abbas (2018) documented that the strach resulting from sago palm can reaches 49 tons dry starch ha-1 ${ }^{-1}$, while other varieties of M. sagu in Papua, Indonesia based on local names such as Para, Panne, Yebha, Wanny have an average dry starch production of $674 \mathrm{~kg}, 576 \mathrm{~kg}, 512 \mathrm{~kg}, 491 \mathrm{~kg}$ tree $^{-1}$ respectively (Yamamoto 2011). Despite this, sago palm forest production was only around $230 \mathrm{~kg}$ tree $\mathrm{e}^{-1}$ dried starch (Yater et al. 2019). Based on morphological and genetic analysis, the sago palm exhibits a lot of variation (Abbas et al. 2017; Abbas 2018; Eksomtramage and Duangpan 2018). Genetic assessment using RAPD markers from $M$. sagu seeds showed significant variety (Riyanto et al. 2018).

Mitochondrial genomes (mt genomes) are circular DNA organelles that are maternally inherited (Castro et al. 1998) and range in size from 222 to $773 \mathrm{~kb}$ for angiosperm (Kitazaki and Kubo 2010). The nad2 is one of many genes in mitochondrial genome that is possibility used for genetic characterization and description of organism. The $\mathrm{mt}$ genome structure was not influenced by the presence of crosses pollination. Dissociation mitochondrial DNAs (mtDNA) in the plant genome were stated that caused by the evolution through insertion or deletion in a long time, approximately 10,000 to100,000 years (Mower et al. 2007). Pervaiz et al. (2015) stated that the mt genome of Prunus species has a high conservative level. In the maternal inherited marker such as mtDNA and cpDNA markers, genetic differentiation occurs in extremely modest levels (Petit et al. 2005). The mitochondrial genome of plants ranges in size from 200 to 2,000 kbp (Morley and Nielsen 2017). Mitochondrial genomes have a low mutation rate (Christensen 2013), making them an effective molecular marker for determining sago palm phylogeny. DNA barcoding is an important approach for recognizing the genetic characteristics of plants and other organisms. Singh and Banerjee (2018) showed that DNA barcoding was a reliable approach for intra-species rice identification, distinguishing 54 percent of 286 species using matK and rbcL as markers (Kuzmina et al. 2012). DNA barcoding is a method of identifying species using one or more short gene sequences extracted from standard genomic sections. The chloroplast genome contains several genes that can be utilized for DNA coding in plants, including the accD, matK, ndhJ, rpoB2, rpoC1, and ycf5 genes (Chase et al. 2007) and nad2 gene is located in the electron transport complex I that possessive conserve protein (Alberola et al. 2019).

The Plant Working Group of the Consortium for the Barcoding of Life (CBoL) (2009) recommended three genes, namely rbcL, matK, and ITS. In the field of plant taxonomy and phylogenetics, DNA barcoding may be used 
to classify plants more correctly than morphological identification. MatK, a chloroplast gene situated on the trnK intron, is the DNA coding used in this study. It is roughly 1500 base pairs long (bp). In most Angiosperms, matK has a base length of up to $1500 \mathrm{bp}$ and is found between exons 5 and 3 of the tRNA-lysine gene (Kar et al. 2015). According to Hollingsworth et al. (2011), the matK gene is now an important tool for studying intra-species and inter-species genetic variability.

The aims of this study were to explore nucleotide sequence of nad2 gene associated in the genome mitochondrial and sequence plastid associated with matK genes in the sago palm to reveal molecular characteristic and evolutionary relationship of sago palm accessions for subjected to new variety of $M$. sagu.

\section{MATERIALS AND METHODS}

\section{Plant materials}

Sago palm used in the studies were obtained from several regions in Papua that has been collected by the Sago Palm Research Center (SRC), University of Papua (UNIPA), Indonesia in 2017. DNA analysis was conducted in 2019. Leaf samples were taken from accessions of sago palm in a growth russet stage. The names of accessions are Sagu1, Sagu2, Sagu3, Sagu4, Sagu5, Sagu6, Sagu7, Sagu8, Sagu9, Sagu10, and Sagu11, Sagu 12, Sagu 13, Sagu14 and Sagu15. The surface of the young leaf samples was cleaned with an alcoholic tissue and brought to the Laboratory of Biotechnology, University of Papua, Indonesia for DNA isolation.

\section{DNA isolation}

Leaf tissue dissociation was done by grind the sample to a fine powder. As much as $20 \mathrm{mg}$ fine powder of the sample were transfer to a $1.5 \mathrm{ml}$ micro centrifuge tube. DNA isolation was done by following the procedure of Plant Genomic DNA Mini Kit (Geneaid 2012). The procedures of DNA isolation using Geneaid protocols are tissue dissociation, lysis, DNA binding, wash, and DNA elution. The genomic DNAs is stored at $-20^{\circ} \mathrm{C}$ freezer before PCR preparation.

\section{PCR and sequencing}

The $n a d 2$ and $m a t \mathrm{~K}$ primer sets were used in this study it is adopted from Duminil et al. (2002) and Kuzmina et al. (2012), respectively. The primer sets were synthesized by Integrated DNA technology (IDT), Singapore 117610. Primer sets for nad2 gene as follows forward 5' TTC ATA TAG AAT CCA TGT CC 3'and reverse 5' CTA TTT GTT CTT CGC CGC TT 3' and for matK gene as follows MatK-1RKIM-f

ACCCAGTCCATCGAAATCTTGGTTC-3 and MatK3FKIM-r 5'-CGTACAGTACTTTTT GTGTTACGAG-3'. PCR mixtures and cycles condition of both nad2 and mat $\mathrm{K}$ genes were followed by $25 \mu \mathrm{l}$ total volume that contains: 1 X PCR buffer contained $1.5 \mathrm{mM} \mathrm{MgCl} 2$ (KAPA 2G Robust HotStart), $10 \mathrm{mM}$ dNTP mix, $10 \mu \mathrm{M}$ of forward and reverse primer, $1 \times$ KAPA Enhancer, 0.5 U KAPA $2 \mathrm{G}$
Robust Hotstar polymerases and $10 \mathrm{ng}$ genomic DNA. PCR cycles condition as follows: initial denaturation for 15 seconds at $94^{\circ} \mathrm{C}$, followed by 30 cycles of denaturation for 30 seconds at $94^{\circ} \mathrm{C}$, annealing for 30 seconds at $50^{\circ} \mathrm{C}$, for 45 seconds extension at $72^{\circ} \mathrm{C}$. PCR amplification fragments were separated on $1 \%$ agarose gels by electrophoresis, staining was done using Ethidium Bromide and visualization by using UV illumination apparatus. Sequencing and purification of DNA PCR product were performed by 1st Base Asia, Singapore 117610.

\section{Data analysis}

Both mitochondrial $n a d 2$ and chloroplast matK DNA sequences in the form of electropherogram were edited and checked to obtain correct DNA sequence. Editing and proofreading sequences were performed by comparing the peak color of both forward and reverse the electropherogram to the sequence of nucleotides produced using Molecular Evolutionary Genetic Analysis (MEGA) version 11 software (Tamura.et al. 2021). Each sequence in this study was obtained from the forward and reverse sequences of each sample. The editing result of a nucleotide sequence is stored in the fasta file format. Cluster alignment were performed based on Clustal W with MEGA 11 version software. Comparison of sample sequences with GenBank database (NCBI) is done using Basic Local Alignment Search Tools (BLAST) available on the National Center for Biotechnology Information (NCBI) web (Zhang et al. 2000; Morgulis et al. 2008). Evolutionary analysis of sago palm accession based on nad 2 gene and matK gene were calculated by using Mega 11 software (Tamura et al. 2021).

\section{RESULTS AND DISCUSSION}

\section{Nucleotide sequence editing}

Sequencing results of nucleotide were edited and alignment by using MEGA 11 version for obtaining the true nucleotide sequence and ensure that the DNA from the PCR results is not contaminated. Editing and alignment of nad2 nucleotide sequence on $M$. sagu show that fifteen accessions were observed, confirmed and declared eight perfect sequences for nad2-gene, others seven accessions were predicted contamination (Table 1). Editing and alignment of mat $\mathrm{K}$ nucleotide sequences on intra-species of M. sagu show overall fifteen accessions confirmed perfect sequences. The numbers of nad 2 and matK nucleotide sequence on $M$. sagu were identified 1304 and 603-767 bases length respectively.

The nucleotide sequences as molecular characteristic identities on intra-species of $M$. sagu that were inferred from mitochondrial $n a d 2$ gene and chloroplast mat $\mathrm{K}$ genes were registered in the GenBank, NCBI (Table 1). Mitochondrial sequences associated with nad2 genes in the sago palm accessions showed that no differences. The results are in agreement with Abbas et al. (2019) and Wulandari et al. (2021) reported. 
Table 1. Identities of Metroxylon sagu accessions based on mitochondrial nad 2 gene and chloroplast mat $\mathrm{K}$ gene

\begin{tabular}{lllllll}
\hline \multirow{2}{*}{ Accession } & \multicolumn{9}{c}{ Nucleotide of nad2 and matK gene } \\
\cline { 2 - 7 } & Nucleotide ID & Protein ID & bp Number & Nucleotide ID & Protein ID & bp number \\
\cline { 2 - 7 } & NA & NA & NA & MT557585.1 & QWN59107.1 & 603 \\
Sagu1 & NA & NA & NA & MT557586.1 & QWN59108.1 & 603 \\
Sagu2 & KY849955.1 & Intron & 1304 & MK860160.1 & QGJ03632.1 & 767 \\
Sagu3 & KY849956.1 & Intron & 1304 & MK860161.1 & QGJ03633.1 & 767 \\
Sagu4 & KY849957.1 & Intron & 1304 & MK860162.1 & QGJ03634.1 & 767 \\
Sagu5 & KY849958.1 & Intron & 1304 & MK860163.1 & QGJ03635.1 & 767 \\
Sagu6 & KY849959.1 & Intron & 1304 & MK860164.1 & QGJ03636.1 & 767 \\
Sagu7 & KY849960.1 & Intron & 1304 & MT557587.1 & QWN59109.1 & 603 \\
Sagu8 & KY849961.1 & Intron & 1304 & MK860165.1 & QGJ03637.1 & 767 \\
Sagu9 & KY849962.1 & Intron & 1304 & MK860166.1 & QGJ03638.1 & 767 \\
Sagu10 & NA & NA & NA & MK860167.1 & QGJ03639.1 & 767 \\
Sagu11 & NA & NA & NA & MT557588.1 & QWN59110.1 & 603 \\
Sagu12 & NA & NA & NA & MK860168.1 & QGJ03640.1 & 767 \\
Sagu13 & NA & NA & NA & MK860169.1 & QGJ03641.1 & 767 \\
Sagu14 & NA & NA & NA & MT557589.1 & QWN59111.1 & 603 \\
Sagu15 & NA &
\end{tabular}

Note: not available (NA), protein presented in Table $2\left(^{*}\right)$, identity (ID), base pair (bp), NADH dehydrogenase subunit 2 (nad2), and maturase $\mathrm{K}$ (mat $\mathrm{K})$

Fifteen accessions for sequencing of sago palm were performed, but other seven accessions were figured out that their sequence contaminated. The peaks of electropherograms of those seven accessions were not clear separation. The nad2 gene sequences of eight intra-species of $M$. sagu showed no differences event the morphological different (Abbas et al. 2017). Based on investigation of mitochondrial genome in the previous studied such as beet showed that plant mitochondrial genome possesses a low mutation rate, a little compactness, large size, and high rearrange structure (Darracq et al. 2011). Furthermore, it was reported that $\mathrm{mt}$ genome of plants have a mechanism of base excision repair pathway (Boesch et al. 2009) so that the nucleotide structure is very conservative, even though morphologically different. Morphological differences were probably controlled by multigenic function which is associated in the nucleus and mitochondrial, or chloroplast genome, such as young petiole color, spine types, and spear color. Genes associated with mitochondrial genome such as nad 2 gene were generally known their function as energy regulation in biological metabolism. Chen et al. (2017) reported that the mitochondria is responsible as primary source of cellular energy for growth, development, and reproduction of organism.

The mitochondrial sequences of nad2 gene in sago palm were observed in this study it does not different. This mean sagu3 to Sagu10 is the same based on on nad2 genes, others Sagu01, Sagu02, Sagu11, Sagu12, Sagu13, Sagu14, and Sagu15 data does not avalaible. The chloroplast sequences associated with matK genes on $M$. sagu were shown two haplotypes based on the matK gene sequence (Table 2). Haplotype-1 was identified on Sagu03, Sagu04, Sagu05, Sagu06, Sagu07, Sagu09, Sagu10, Sagu11, Sagu13, and Sagu14, and Haplotypes-2 was identified on Sagu01, Sagu02, Sagu08, Sagu12 and Sagu15 (Table 2). Nucleotide characteristic of Haplotype-1 was identified by Thymine (T) base in the position of nucleotide 5 th base and 16th base. On the other hand, nucleotide substitutions of Haplotype- 2 were identified by adenine (A) base in the position site of nucleotide base 5th and nucleotide deletion in the position site of nucleotide base 16th (Table-3). These characteristics revealed that the mat $K$ gene in the sago palm genome is highly conserved, with only two nucleotide tide changes of 604 to 767 base nucleotide sequences. Provan et al. (1999) observed very low mutation rates in the range of $3.2 \times 10-5$ to $7.9 \times 10-5$ in the chloroplast genome. According to Selvaraj et al. (2008) both chloroplast genome and mitochondrial genome of sago palm belong to highly conserved DNA sequences. The nuclear genome of the sago palm from the Papua Islands, on the other hand, was found to be highly variable using the RAPD marker (Abbas et al. 2009; Abbas 2018; Riyanto et al. 2018). Sagu01, Sagu02, Sagu08, Sagu12, and Sagu15 have mutated in the location of two nucleotides base in the DNA sequence organization, according to the matK sequence of sago palm genotypes-2. Thymine to adenine base mutation is the first nucleotide base mutation, and thymine base deletion is the second nucleotide base mutation (Table 3). One of the explanations for the low mutation rate of the chloroplast genome is that it is inherited uniparentally (Savolainen et al. 1995; Viard et al. 2001).

\section{Nucleotide characteristic of nad2 and matK gene}

The Nucleotide sequences in the nad2 gene were alleged as intron and the nucleotide sequences in the mat $\mathrm{K}$ gene were observed as exon. The nucleotide matK sequence on intra-species of $M$. sagu was observed and declared two haplotypes (Table 2). The arrangement and nucleotide combination of the nad2 gene in intra-species $M$. sagu showed that only one haplotype was found, meaning there was no difference at the intra-species level of $M$. sagu. The nucleotide arrangement and combination of the mat $\mathrm{K}$ gene is divided into two genetic categories, namely haplotype- 1 and haplotype- 2 .

The observations of nucleotide frequency from $n a d 2$ gene showed that thymine (T) and cytosine (C) were $27.1 \%$ and $25.9 \%$, respectively, in Sagu03, Sagu04, and Sagu05, 
while for Sagu06, Sagu07, Sagu08, Sagu09, and Sagu10 had the frequency thymine (T) and cytosine (C) nucleotides were $27.0 \%$ and $26.0 \%$, respectively. The frequency of guanine $(\mathrm{G})$ was $22.3 \%$, and adenine was $24.7 \%$ for all individual samples (Table 4). The observation of nucleotide frequency from the mat $\mathrm{K}$ gene showed that thymine $(\mathrm{T})$ in haplotype-1 differed from the nucleotide frequency (T) in haplotype-2. The frequency (T) of Haplotype-1 is $36.1 \%$ and Haplotype-2 is $36.4 \%$. The nucleotides frequency of cytosine $(\mathrm{C})$ and guanine $(\mathrm{G})$ was the same for haplotype-1 and Haplotype-2, namely $17 \%$ and $16.3 \%$, respectively. Adenine (A) nucleotide frequency was $30.6 \%$ for Haployipe-1 and $30.4 \%$ for haplotype-2 (Table 4). The highest frequencies of the nucleotide in both $\operatorname{nad} 2$ and matK gene were calculated thymine. Louie et al. (2003) reported that nucleotide composition may use as mark for identifying eukaryotic organism. There is a clear GC and TA bias in introns, with an excess of $\mathrm{G}$ over $\mathrm{C}$ and $\mathrm{T}$ over
A. This bias can be found in all noncoding, transcribed genes. The action of the transcription-coupled DNA repair system is most likely to blame (Green et al. 2003). The bias can be detected up to 1000 bp after the transcription ends. This is because the fact that transcription usually continues past the poly(A) signal, and the pre-mRNA is cleaved at the signal sequence before the poly $(\mathrm{A})$ tail is added (Dye and Proudfoot 2001). Polypyrimidine tracts (PPT) and branch sites are known to be found at the $3^{\prime}$ intron ends (Louie et al. 2003). Within the last 40 nucleotides, there is an increase in $\mathrm{C}$ and $\mathrm{T}$ content. Aside from that, both intron ends appear to be roughly symmetrical. The endpoints are $\mathrm{C}$ and G-rich, owing to an overabundance of GGG (involved) at least in part. PPT and branch sites are known to be found at the $3^{\prime}$ intron ends. McCullough and Schuler (1997) reported that AU-rich intronic sequences, AG-rich exonic sequences and the $5^{\prime}$ splice site itself collectively define $5^{\prime}$ intron boundaries in dicot nuclei.

Table 2. Sequence alignment of nad2 gene and matK gene on accessions of Metroxylon sagu

\begin{tabular}{|c|c|c|}
\hline Gene & Accession & Sequence alignment \\
\hline $\operatorname{nad2}$ & $\begin{array}{l}\text { Haplotype-1 } \\
\text { Sagu03 } \\
\text { Sagu04 } \\
\text { Sagu05 } \\
\text { Sagu06 } \\
\text { Sagu07 } \\
\text { Sagu08 } \\
\text { Sagu09 } \\
\text { Sagu10 }\end{array}$ & $\begin{array}{l}\text { TCCGAACCGCAGGAGATAGTTGCCCATCATACGGCTCACCAACTTCACTTGCCTCTAAGGGGGGCTCGCT } \\
\text { CCGGGCAGGTTCGGATCACTTACAATACACGGCTCTACGAAGGGGTTAGGAGCGTTTTCAAGATGATTCT } \\
\text { TTCTTTGTCGAGACGAAAAAGGAACCCATTTTTTCGACTGGAAAATGGGAGTCTGTTTTGTCTACTTTAT } \\
\text { CCATCCCCCTCTATCAAAATGATCAAAAAGGAAGGTGAGCTTGCTTCTTATTCCCGTGTTTGATCTTTC } \\
\text { CATCTCTGCCCCGCTTCCATGTGGGCAGAGACCCCTGTAGAGAATGAAGAGGGGCCAAGGATCTTCCTCT } \\
\text { CAAGAGTGCTTCTCGAGGCTCCACTCTCTCCCCTGAATAAGTAAGGCTCCGTTAGCCTGGGCTGAGATGG } \\
\text { GGATAAGGAGTCAGGATTGAAGCCCCCAACGTTCTGCCAGACACTGGACAGGGGTTAGCTCTGTAAATGT } \\
\text { GTAGAGCCAAGTGTAGTGTGGTGTAGTAGTAGGCACTTCTAGGCCCCTTCCCGGCTACTGGATCACTCCA } \\
\text { GTGCTTCGGGTACTACGGACCCTCTGCCATCCATTGCAGCAGAGCCGTTTCATGAGCGGGGGGGCTAAGC } \\
\text { GCAGTTCTTTGAATCAAACGTTGAATGAAATCGAATCGATTCTTTTTTAGATATCCGGATAGATGGATG } \\
\text { GATCTATCTTTCTATTCATATATATTTTGCAAGAAGCCCCAAATCCTTGATTTGGCCAGGAAACAAAGCA } \\
\text { CTGCTTTGGGCCCAGGAAGCGAAGGGATGAGCTCGGCTGCTTCTCCTCCACACTTCTTTATTTCTCCGT } \\
\text { GCCCGTTCCGCATGCGCTTCGCGCGCCATTGGCGCTTTGCTCTCCTCTTATTTCTTCATTGGACGGTTCG } \\
\text { GATGGACTTCGCCGTTCTTTCCCAACGAAAATGGAAAGGCTGTATCACATCGAGATGTCGATTCGTTTT } \\
\text { CCGCCCCAAATGAGATGGGGAATTAGTCACCTCTGTCCCTTCATCTTTCTGAATTGAATCGAGGCCCGGC } \\
\text { CCGGCTCGCGTCGTTCCAACAACCGACGGGGAGCACCTCAGTATACGATCGCGCGCAGTAACTGGGAGTC } \\
\text { CTATTACACCGGCGGCCAACTTCCATTCACCAAACCCAGGTTCATCTCGTGTAGTGATTGTGGACTCGTA } \\
\text { CAAGGATATGGAGTCGACGGTTGATGTATCAGACTCGACCCT GTCTTTCGTAGCATGCATTCCCATCCGT } \\
\text { GTCGCAACTGATTCGGTAAGCTACGTGTCCGGTGCACGGAAAAC }\end{array}$ \\
\hline mat $\mathrm{K}$ gene & $\begin{array}{l}\text { Haplotype-1 } \\
\text { Sagu3 } \\
\text { Sagu4 } \\
\text { Sagu5 } \\
\text { Sagu6 } \\
\text { Sagu7 } \\
\text { Sagu9 } \\
\text { Sagu10 } \\
\text { Sagu11 } \\
\text { Sagu13 } \\
\text { Sagu14 }\end{array}$ & $\begin{array}{l}\text { TTATTGCGATTCTTTCTTCACGAATATCATAATTGGAATAGTCTTATTACTCCGAATAATTCTATTTTT } \\
\text { TTTTTTTTTTGAAAAAAAAATAAAAGACTATTTCGGTTCCTATATAATTCTTATGTATCTGAATGCGA } \\
\text { ATTTGTATTAGTTTTCTTCGTAAACAATCTTCTTATTACGATAACATCTTCTGGAGCTTTCTTGA } \\
\text { CGAACACATTTCTATGGAAAAATAGAACATCTTATAGTAGTGCGCCATAATTATTTTCA GAGGACCCTAT } \\
\text { GGTCCTTCAAGGATCCTTCATGCATTATGTTCGATATCAAGGAAAAGCAATTCTGGTTTCAAAGGGGGC } \\
\text { TCATCTTCTGATGAAGAAATGGAATGTCACCTTGTCAATTTCTGGCAATATCATTTTCACTTTTGGTCT } \\
\text { CAACCGTACAGGATCCATATAGACCAATTATCAAACTGTTCTTTCTATTTTCTAGGTTATCTTTCAAGTG } \\
\text { TATTAATAAATCTTTCGACGGTAAGGAATCAAATGCTAGAGAATTCATTTCTAATGGATACTGTTACTAA } \\
\text { AAAATTCGATACCAGAGTCCCAGTTATTCCTCTTATTGAATCATTGTCTAAAGCAAAATTTTGTACCGTA } \\
\text { TCGGGGCACCCTATTAGTAAGCCGATCTGGACCGATTTATCAGATTGCGATATTATTGATCGATTTGGTC } \\
\text { GGATATGTAGAAATCTTTCTCATTATCACAGTGGATCCTCAAAAAAACAGAGTTTGTATCGAATAAA }\end{array}$ \\
\hline & $\begin{array}{l}\text { Sagu01 } \\
\text { Sagu02 } \\
\text { Sagu08 } \\
\text { Sagu12 } \\
\text { Sagu15 }\end{array}$ & $\begin{array}{l}\text { TTATTTTTTTTTGAAAAAGAAAATAAAAGACTATTTCGGTTCCTATATAATTCTTATGTATCTGAATGC } \\
\text { GAATTTGTATTAGTTTTCTTCGTAAACAATCTTCTTATTTACGATTAACATCTTCTGGAGCTTTTCTTG } \\
\text { AGCGAACACATTTCTATGGAAAAATAGAACATCTTATAGTAGTGCGCCATAATTATTTCAGAGGACCCT } \\
\text { ATGGTCCTTCAAGGATCCTTTCATGCATTATGTTCGATATCAAGGAAAAGCAATTCTGGTTTCAAAGGGG } \\
\text { GCTCATCTTCTGATGAAGAAATGGAAATGTCACCTTGTCAATTTCTGGCAATATCATTTTCACTTTTGGT } \\
\text { CTCAACCGTACAGGATCCATATAGACCAATTATCAAACTGTTCTTTCTATTTTCTAGGTTATCTTTCAAG } \\
\text { TGTATTAATAAATCTTTCGACGGTAAGGAATCAAATGCTAGAGAATTCATTCTAATGGATACTGTTACT } \\
\text { AAAAAATTCGATACCAGAGTCCCAGTTATTCCTCTTATTGAATCATTGTCTAAAGCAAAATTTTGTACCG } \\
\text { TATCGGGGCACCCTATTAGTAAGCCGATCTGGACCGATTTATC }\end{array}$ \\
\hline
\end{tabular}

Note: The length of haplotype one for nad 2 gene is 1304 bp and the length of haplotype-1 and haplotype-2 for matK gene are 767 bases and 603 bases, respectively 
Table 3. An example of nucleotide sequence in the mutation sites and deletion sites

\begin{tabular}{|c|c|c|}
\hline Genotypes & Accessions & Alignment nucleotide sequence \\
\hline \multirow{10}{*}{ Genotype-1 } & Sagu03 & TTTTTTTTTTTTTTTTGAAAAAGAAAATAAAAGACTATTTCGGTT \\
\hline & Sagu04 & TTTTTTTTTTTTTTTGAAAAAGAAAATAAAAGACTATTTCGGTT \\
\hline & Sagu05 & TTTTTTTTTTTTTTTGAAAAAGAAAATAAAAGACTATTTCGGTT \\
\hline & Sagu06 & TTTTTTTTTTTTTTTTGAAAAAGAAAATAAAAGACTATTTCGGTT \\
\hline & Sagu07 & TTTTTTTTTTTTTTTTGAAAAAGAAAATAAAAGACTATTTCGGTT \\
\hline & Sagu09 & TTTTTTTTTTTTTTTTGAAAAAGAAAATAAAAGACTATTTCGGTT \\
\hline & Sagu10 & TTTTTTTTTTTTTTTTGAAAAAGAAAATAAAAGACTATTTCGGTT \\
\hline & Sagu11 & тTтTтTтTтTтTTTGAAAAAGAAAATAAAAGACTATTTCGGTT \\
\hline & Sagu13 & тTтTтTтTтTTTTTTGAAAAAGAAAATAAAAGACTATTTCGGTT \\
\hline & Sagu14 & TTTTTTTTTTTTTTTTGAAAAAGAAAATAAAAGACTATTTCGGTT \\
\hline \multirow[t]{5}{*}{ Genotype-2 } & Sagu01 & тTтTATтTTтTтTT-GAAAAAGAAAATAAAAGACTATTTCGGTT \\
\hline & Sagu02 & тTTTATTTTTTTTTT-GAAAAAGAAAATAAAAGACTATTTCGGTT \\
\hline & Sagu08 & TTTTATTTTTTTTTT-GAAAAAGAAAATAAAAGACTATTTCGGTT \\
\hline & Sagu12 & тTтTATTTTTTTTTT-GAAAAAGAAAATAAAAGACTATTTCGGTT \\
\hline & Sagu15 & TTTTATTTTTTTTTT-GAAAAAGAAAATAAAAGACTATTTCGGTT \\
\hline
\end{tabular}

Table 4. Nucleotide frequencies of nad 2 gene and matK gene on accessions of Metroxylon sagu

\begin{tabular}{|c|c|c|c|c|c|c|c|c|}
\hline \multirow{3}{*}{ Accession } & \multicolumn{8}{|c|}{ Nucleotide frequency $(\%)$} \\
\hline & \multicolumn{4}{|c|}{ nad2 gene } & \multicolumn{4}{|c|}{ matK gene } \\
\hline & $\mathbf{T}$ & $\mathbf{C}$ & $\mathbf{A}$ & $\mathbf{G}$ & $\mathbf{T}$ & $\mathbf{C}$ & $\mathbf{A}$ & $\mathbf{G}$ \\
\hline Sagu 01 & NA & NA & NA & NA & 36.1 & 17.0 & 30.6 & 16.3 \\
\hline Sagu 02 & NA & NA & NA & NA & 36.1 & 17.0 & 30.6 & 16.3 \\
\hline Sagu 03 & 27.1 & 25.9 & 22.3 & 24.7 & 36.4 & 17.0 & 30.4 & 16.3 \\
\hline Sagu 04 & 27.1 & 25.9 & 22.3 & 24.7 & 36.4 & 17.0 & 30.4 & 16.3 \\
\hline Sagu 05 & 27.1 & 25.9 & 22.3 & 24.7 & 36.4 & 17.0 & 30.4 & 16.3 \\
\hline Sagu 06 & 27.0 & 26.0 & 22.3 & 24.7 & 36.4 & 17.0 & 30.4 & 16.3 \\
\hline Sagu 07 & 27.0 & 26.0 & 22.3 & 24.7 & 36.4 & 17.0 & 30.4 & 16.3 \\
\hline Sagu 08 & 27.0 & 26.0 & 22.3 & 24.7 & 36.1 & 17.0 & 30.6 & 16.3 \\
\hline Sagu 09 & 27.0 & 26.0 & 22.3 & 24.7 & 36.4 & 17.0 & 30.4 & 16.3 \\
\hline Sagu 10 & 27.0 & 26.0 & 22.3 & 24.7 & 36.4 & 17.0 & 30.4 & 16.3 \\
\hline Sagu 11 & NA & NA & NA & NA & 36.4 & 17.0 & 30.4 & 16.3 \\
\hline Sagu 12 & NA & NA & NA & NA & 36.1 & 17.0 & 30.6 & 16.3 \\
\hline Sagu 13 & NA & NA & NA & NA & 36.4 & 17.0 & 30.4 & 16.3 \\
\hline Sagu 14 & NA & NA & NA & NA & 36.4 & 17.0 & 30.4 & 16.3 \\
\hline Sagu 15 & NA & NA & NA & NA & 36.1 & 17.0 & 30.6 & 16.3 \\
\hline
\end{tabular}

Notes: not available (NA)

\section{Amino acid characteristic of nad2 and matK gene}

This work does not describe nad 2 protein caused by the nucleotide allegedly as intron, so in the process transcription just until precursor messenger RNA (premRNA) and removing when the transcription and translation process to be mature messenger RNA (mRNA) as well as protein translation respectively. Intron sequences do not participate in protein-coding sequences (Jo and Choi 2015). According to Amini et al. (2014), intron remove by catalytic RNAs (ribozymes). Amino acid frequencies of matK gene were presented in Table 4. There were as many as 20 different types of amino acids found in this investigation, namely Ala, Cys, Asp, Glu, Phe, Gly, His, Ile, Lys, Leu, Met, Asn, Pro, Gln, Arg, Ser, Thr, Val, Trp, and Tyr. The composition of haplotype-1 was found to be different from that of haplotype-2. Leucine was the amino acid with the highest frequency, at $11.44 \%$ for Haplotype-1 and $11.50 \%$ for Haplotype-2. The amino acids Alanine, Cysteine, and Methionine have the lowest rates, with $1.99 \%$ for Haplotype-1 and $2.00 \%$ for Haplotype-2 (Table 4). Gorissen et al. (2018) stated that large differences in essential amino acid (EAA) contents and amino acid (AA) composition between various plantbased protein isolates. The EAAS were observed in this study that are Leucine, Isoleusine, Valine, Lysine, Histidine, Phenylalanine, Methionine, and Threonine. The highest proportion of the EAAs in the chloroplast matK gene of $M$. sagu was found EAA Isoleucine (Table 4). Determine characteristics of plant may be inferred from the amino acid. Chauhan et al (2020) found that the diversity of plant by using AA sequence and Brooks et al. (2002) explained the evolution of amino acid frequencies over long time. Mutation within exon may be resulting amino acid change. In the previous study was shown that change Cysteine to Phenylalanine at codon 706 in cell demonstrated was sufficient to inhibit phosphorylation (Kaye et al. 1990). Proteins from the Last Universal Ancestor (LUA) were discovered to be usually richer in amino acids that are thought to have been most abundant in the prebiotic environment, and poorer in amino acids that are thought to have been unavailable or sparse (Brooks et al. 2002). 
Table 5. Amino acid frequencies (\%) in matK gene on accessions of Metroxylon sagu

\begin{tabular}{|c|c|c|c|c|c|c|c|c|c|c|c|c|c|c|c|c|c|c|c|c|c|c|}
\hline Genotype & Accession & Ala & Cys & Asp & Glu & Phe & Gly & His & Ile & Lys & Leu & Met & Asn & Pro & Gln & Arg & Ser & Thr & Val & Trp & Tyr & Total \\
\hline \multirow[t]{10}{*}{ Haplotype-1 } & Sagu03 & 1.99 & 1.99 & 2.49 & 3.98 & 10.95 & 2.99 & 4.98 & 4.98 & 7.46 & 11.44 & 1.99 & 3.98 & 2.99 & 3.48 & 5.47 & 9.45 & 4.48 & 6.97 & 2.49 & 5.47 & 201 \\
\hline & Sagou4 & 1.99 & 1.99 & 2.49 & 3.98 & 10.95 & 2.99 & 4.98 & 4.98 & 7.46 & 11.44 & 1.99 & 3.98 & 2.99 & 3.48 & 5.47 & 9.45 & 4.48 & 6.97 & 2.49 & 5.47 & 201 \\
\hline & Sagu05 & 1.99 & 1.99 & 2.49 & 3.98 & 10.95 & 2.99 & 4.98 & 4.98 & 7.46 & 11.44 & 1.99 & 3.98 & 2.99 & 3.48 & 5.47 & 9.45 & 4.48 & 6.97 & 2.49 & 5.47 & 201 \\
\hline & Sagu06 & 1.99 & 1.99 & 2.49 & 3.98 & 10.95 & 2.99 & 4.98 & 4.98 & 7.46 & 11.44 & 1.99 & 3.98 & 2.99 & 3.48 & 5.47 & 9.45 & 4.48 & 6.97 & 2.49 & 5.47 & 201 \\
\hline & Sagu07 & 1.99 & 1.99 & 2.49 & 3.98 & 10.95 & 2.99 & 4.98 & 4.98 & 7.46 & 11.44 & 1.99 & 3.98 & 2.99 & 3.48 & 5.47 & 9.45 & 4.48 & 6.97 & 2.49 & 5.47 & 201 \\
\hline & Sagu09 & 1.99 & 1.99 & 2.49 & 3.98 & 10.95 & 2.99 & 4.98 & 4.98 & 7.46 & 11.44 & 1.99 & 3.98 & 2.99 & 3.48 & 5.47 & 9.45 & 4.48 & 6.97 & 2.49 & 5.47 & 201 \\
\hline & Sagu10 & 1.99 & 1.99 & 2.49 & 3.98 & 10.95 & 2.99 & 4.98 & 4.98 & 7.46 & 11.44 & 1.99 & 3.98 & 2.99 & 3.48 & 5.47 & 9.45 & 4.48 & 6.97 & 2.49 & 5.47 & 201 \\
\hline & Sagu11 & 1.99 & 1.99 & 2.49 & 3.98 & 10.95 & 2.99 & 4.98 & 4.98 & 7.46 & 11.44 & 1.99 & 3.98 & 2.99 & 3.48 & 5.47 & 9.45 & 4.48 & 6.97 & 2.49 & 5.47 & 201 \\
\hline & Sagu13 & 1.99 & 1.99 & 2.49 & 3.98 & 10.95 & 2.99 & 4.98 & 4.98 & 7.46 & 11.44 & 1.99 & 3.98 & 2.99 & 3.48 & 5.47 & 9.45 & 4.48 & 6.97 & 2.49 & 5.47 & 201 \\
\hline & Sagu14 & 1.99 & 1.99 & 2.49 & 3.98 & 10.95 & 2.99 & 4.98 & 4.98 & 7.46 & 11.44 & 1.99 & 3.98 & 2.99 & 3.48 & 5.47 & 9.45 & 4.48 & 6.97 & 2.49 & 5.47 & 201 \\
\hline \multirow[t]{5}{*}{ Haplotype-2 } & Sagu01 & 2.00 & 2.00 & 2.50 & 4.00 & 10.00 & 3.00 & 5.00 & 5.50 & 7.50 & 11.50 & 2.00 & 4.00 & 3.00 & 3.50 & 5.50 & 9.50 & 4.50 & 7.00 & 2.50 & 5.50 & 200 \\
\hline & Sagu02 & 2.00 & 2.00 & 2.50 & 4.00 & 10.00 & 3.00 & 5.00 & 5.50 & 7.50 & 11.50 & 2.00 & 4.00 & 3.00 & 3.50 & 5.50 & 9.50 & 4.50 & 7.00 & 2.50 & 5.50 & 200 \\
\hline & Sagu08 & 2.00 & 2.00 & 2.50 & 4.00 & 10.00 & 3.00 & 5.00 & 5.50 & 7.50 & 11.50 & 2.00 & 4.00 & 3.00 & 3.50 & 5.50 & 9.50 & 4.50 & 7.00 & 2.50 & 5.50 & 200 \\
\hline & Sagu12 & 2.00 & 2.00 & 2.50 & 4.00 & 10.00 & 3.00 & 5.00 & 5.50 & 7.50 & 11.50 & 2.00 & 4.00 & 3.00 & 3.50 & 5.50 & 9.50 & 4.50 & 7.00 & 2.50 & 5.50 & 200 \\
\hline & Sago15 & 2.00 & 2.00 & 2.50 & 4.00 & 10.00 & 3.00 & 5.00 & 5.50 & 7.50 & 11.50 & 2.00 & 4.00 & 3.00 & 3.50 & 5.50 & 9.50 & 4.50 & 7.00 & 2.50 & 5.50 & 200 \\
\hline \multicolumn{23}{|c|}{$\begin{array}{l}\text { Notes: Alanine (Ala) Cysteine (Cys), Aspartic (Asp), Glutamic (Glu), Phenylalanine (Phe), Glycine (Gly), Histidine (His), Isoleucine (Ile), Lysine (Lys), Leucine (Leu), Methionine (Met), } \\
\text { Asparagine (Asn), Proline (Pro), Glutamine (Gln), Arginine (Arg), Serine (Ser), Threonine (Thr), Valine (Val), Tryptophan (Trp), Tyrosine (Tyr) }\end{array}$} \\
\hline Accessions & Sagu01 & Sagu02 & Sag & 103 & Sagu04 & Sag & 405 & Sagu06 & Sa & $\mathbf{u} 07$ & Sagu08 & Sag & 109 & Sagu10 & & gu11 & Sagu12 & & gu13 & Sagu & & Sagu15 \\
\hline Sagu01 & 0.0000 & & & & & & & & & & & & & & & & & & & & & \\
\hline Sagu02 & 0.0000 & 0.0000 & & & & & & & & & & & & & & & & & & & & \\
\hline Sagu03 & 0.0039 & 0.0039 & 0.0 & & & & & & & & & & & & & & & & & & & \\
\hline Sagu04 & 0.0039 & 0.0039 & 0.0 & & 0.0000 & & & & & & & & & & & & & & & & & \\
\hline Sagu05 & 0.0039 & 0.0039 & 0.0 & & 0.0000 & 0.00 & & & & & & & & & & & & & & & & \\
\hline Sagu06 & 0.0039 & 0.0039 & 0.0 & & 0.0000 & 0.00 & & 0.0000 & & & & & & & & & & & & & & \\
\hline Sagu07 & 0.0039 & 0.0039 & 0.0 & & 0.0000 & 0.00 & & 0.0000 & 0.0 & & & & & & & & & & & & & \\
\hline Sagu08 & 0.0000 & 0.0000 & 0.0 & & 0.0039 & 0.00 & & 0.0039 & 0.0 & & 0.0000 & & & & & & & & & & & \\
\hline Sagu09 & 0.0039 & 0.0039 & 0.0 & & 0.0000 & 0.00 & & 0.0000 & 0.0 & 000 & 0.0039 & 0.0 & & & & & & & & & & \\
\hline Sagu10 & 0.0039 & 0.0039 & 0.0 & & 0.0000 & 0.00 & & 0.0000 & 0.0 & 000 & 0.0039 & 0.0 & & 0.0000 & & & & & & & & \\
\hline Sagu11 & 0.0039 & 0.0039 & 0.0 & & 0.0000 & 0.00 & & 0.0000 & 0.0 & & 0.0039 & 0.0 & & 0.0000 & & 000 & & & & & & \\
\hline Sagu12 & 0.0000 & 0.0000 & 0.0 & & 0.0039 & 0.00 & & 0.0039 & 0.0 & & 0.0000 & 0.0 & & 0.0039 & & 039 & 0.0000 & & & & & \\
\hline Sagu13 & 0.0039 & 0.0039 & 0.0 & & 0.0000 & 0.00 & & 0.0000 & 0.0 & 000 & 0.0039 & 0.0 & & 0.0000 & & 000 & 0.0039 & & 0000 & & & \\
\hline Sagu14 & 0.0039 & 0.0039 & 0.0 & & 0.0000 & 0.00 & & 0.0000 & & & 0.0039 & 0.0 & & 0.0000 & & 000 & 0.0039 & & 0000 & 0.000 & & \\
\hline Sagu15 & 0.0000 & 0.0000 & 0.0 & & 0.0039 & 0.00 & & 0.0039 & 0.0 & & 0.0000 & 0.0 & & 0.0039 & & 039 & 0.0000 & & 0039 & 0.003 & & 0.0000 \\
\hline
\end{tabular}




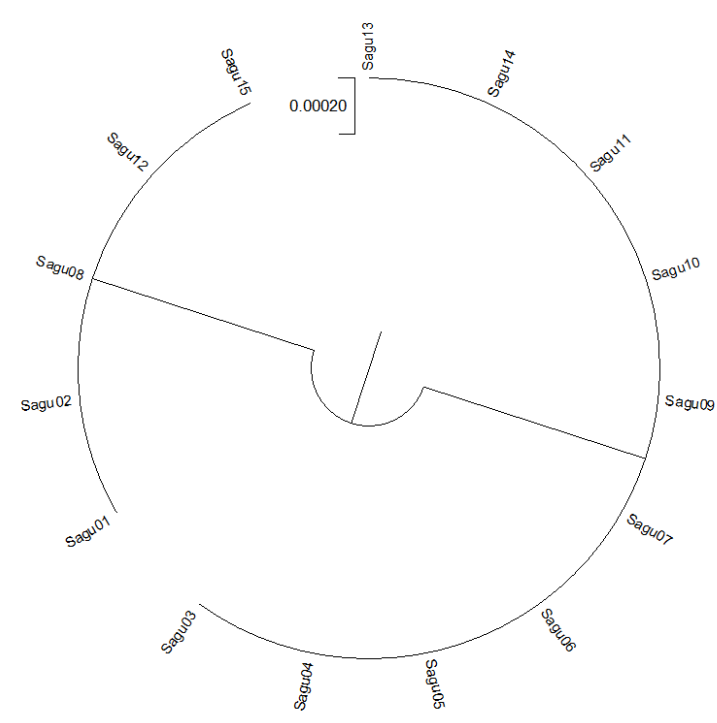

Figure 1. Evolutionary relationships infer by using mat $\mathrm{K}$ gene on accessions of Metroxylon sagu

Genetic distance based on amino acid composition is show among haplotype differentiation with genetic distances equal 0.0039 (Table 6). The previous study was reported that nucleotide differences in intra-species of sago palm by using chloroplast matK gene with genetic distances equal 0.002 (Abbas et al. 20020a). The differentiation of $M$. sagu in the level intra-species show lower and just single nucleotide different as well as indicated mutation. Segregations in the DNA plastid of the matK gene in the sago palm Haplotype-2 were consistent with Dipterocarpaceae phylogenetics based on the matK gene (Harnelly et al. 2018), and corresponded to the Pandanus (palms) DNA barcode (Zebua et al. 2019). DNA barcoding studies on intra-specific mangroves revealed $0.2 \%$ variabilities using the mat K marker (Saddhe et al. 2016), and vascular plants revealed $0.04 \%$ variabilities using the matK marker (Saddhe et al. 2016) and sand rice (Agriophyllum squarroum) revealed $1.8 \%$ variabilities using the matK marker (Genievskaya et al. 2017).

\section{Evolutionary relationships based on nad2 and matK genes}

The nad2 gene was observed not differentiated, so clearly that no occurrence site of the DNAs evolution in the nad2 gene of $M$. sagu. Otherwise, matK gene was calculated differentiation. The branch lengths are in the same units as the genetic distances used to estimate the evolutionary relationships, and the tree is drawn to scale. The evolutionary distances were calculated using the Maximum Composite Likelihood technique (Tamura et al. 2004), and are in base substitutions per site unit. There were 15 accessions of $M$. sagu sequences in this study. $1 \mathrm{st}+2 \mathrm{nd}+3 \mathrm{rd}+$ Noncoding codon locations were included. For each sequence pair, all unclear locations were deleted (pairwise deletion option). In the end, there were 605 positions in the dataset. MEGA11 was used to perform evolutionary analysis (Tamura et al. 2021). The evolutionary relationships in the nucleotide plastid matK gene among intra-species of $M$. sagu are presented in Figure 1 . The results are shown that only two haplotypes were recorded, which mean that lower mutation rates are inferred on intra-species of $M$. sagu (Figure 1). Haplotype1 and haplotype- 2 were observed ten and five samples respectively. The chloroplast mutation rate is lower than mitochondrion mutation rates (Smith 2015). Using the plastid matK gene, the DNA Barcode can be utilized to establish inter- and intra-genera as well as inter-species relationships in the palm family (Abbas et al. 2020b).

In conclusion, molecular characteristics on intra-species of $M$. sagu were shown that the nad2 gene on of $M$. sagu was inferred only one haplotype and the mat $K$ gene were inferred two haplotypes. The highest frequencies of the nucleotide in both nad 2 and matK genes were calculated thymine (T). The amino acid leucine was the most common, accounting for $11.44 \%$ of haplotype- 1 and $11.50 \%$ of haplotype-2. The amino acids Alanine, Cysteine, and Methionine have the lowest rates, with $1.99 \%$ for haplotype- 1 and $2.00 \%$ for haplotype- 2 . The evolutionary relationships were shown that no mutation rates occur in the nad 2 gene and lower mutation rates occur in the matK gene on intra-species of $M$. sagu. The genotype-2 (Sagu01, Sagu02, Sagu08, Sagu12, and Sagu15) is suggested and proposed to be new variety based on molecular characters.

\section{ACKNOWLEDGEMENTS}

The research was financially funded by the Directorate General Strengthen Research and Development Republic Indonesia with contract No. 2020/E4.1/AK.04.PT/2021 and No. 315/UN42.15/PG/2021. The authors gratefully acknowledge the DRPM-DIKTI as the financial funders and Chairman of the Food Security Service of West Papua Province as collaboration.

\section{REFERENCES}

Abbas B, Bintoro MH, Sudarsono, Surahman M, Ehara H. 2009. Genetic relationship of sago palm (Metroxylon sagu Rottb.) in Indonesia based on RAPD markers. Biodiversitas 10 (4): 168-174. DOI: 10.13057/biodiv/d100402.

Abbas B. 2015. Sago commodity as a pillar of food sovereignty that needs to be managed and developed wisely as well as sustainably for community welfare. Scientific Oration for the inauguration of Professor in the University of Papua, Manokwari. [Indonesian]

Abbas B, Paisey EK, Dailami M, Munarti. 2017. Assessment of genetic arrangement of sago palm collection based on mitochondrial nad2 gene Marker. Proceeding of the 13th International Sago Symposium, Kuching Sarawak, Malaysia, 2-6 October 2017.

Abbas B. 2018. Sago palm genetic resource diversity in Indonesia. In: Ehara H, Toyoda Y, Johnson D. (eds.). Sago Palm: Multiple Contributions to Food Security and Sustainable Livelihoods. Springer, Singapore. DOI: 10.1007/978-981-10-5269-9_5.

Abbas B, Tjolli I, Dailami M, Munarti. 2019. Phylogenetic of sago palm (Metroxylon sagu) and others monocotyledon based on mitochondrial nad2 gene markers. Biodiversitas 20 (8): 2249-2256. DOI: 10.13057/biodiv/d200820.

Abbas B, Tjolli I, Munarti. 2020a. Genetic diversity of sago palm (Metroxylon sagu) accessions based on plastid cpDNA matK gene as 
DNA barcoding. Biodiversitas 21 (1): 219-225. DOI: 10.13057/biodiv/d210128.

Abbas B, Kabes RJ, Mawikere NL, Ruimassa RMR, Maturbong RA 2020b. DNA barcode of Metroxylon sagu and others palm species using matK gene. Biodiversitas 21 (9): 4047-4057. DOI: 10.13057/biodiv/d210916.

Alberola FM, Barreno E, Casano LM. Gasulla F, Molins A, Campo EMD. 2019. Dynamic evolution of mitochondrial genomes in Trebouxiophyceae, including the first completely assembled mtDNA from a lichen-symbiont microalga (Trebouxia sp. TR9). Sci Rep 9: 8209. DOI: $10.1038 / \mathrm{s} 41598-019-44700-7$.

Amini ZN, Olson KE, Müller UF. 2014. Spliceozymes: Ribozymes that remove introns from pre-mRNAs in trans. PLoS One 9 (7): e101932. DOI: 10.1371/journal.pone.0101932.

Boesch P, Ibrahim N, Paulus F, Cosset A, Tarasenko V, Dietrich A. 2009 Plant mitochondria possess a short-patch base excision DNA repair pathway. Nucleic Acids Res 37 (17): 5690-5700. DOI: 10.1093/nar/gkp606.

Brooks DJ, Fresco JR, Lesk AM, Singh M. 2002. Evolution of amino acid frequencies in proteins over deep time: inferred order of introduction of amino acids into the genetic code. Mol Biol Evol 19 (10): 16451655. DOI: 10.1093/oxfordjournals. molbeva003 988.

Castro JA, Picornel A, Ramon M. 1998. Mitochondrial DNA: A tool for population genetic studies. Internal Microbial 1: 327-332.

Chase MW, Cowan RS, Hollingsworth PM, Berg CVD, Madrin'an S, Petersen G, Seberg O, Jorsensen T, Cameron KM, Carine M, Pedersen N, Hedderson TAJ, Conrad F, Salazar GA, Richardson JE, Hollingsworth ML, Barraclough TG, Kelly L, Wilkinson M. 2007. A proposal for a standardized protocol to barcode all land plants. Taxon 56 (2): 295-299. DOI: 10.1002/tax.562004

Chauhan V, Kumari V, Kanwar SS. 2020, Comparative analysis of amino acid sequence diversity and physiochemical properties of peroxidase superfamily. J Protein Res Bioinform 2: 003. DOI: 10.24966/PRB$1545 / 100003$.

Chen ZD, Yang T, Lin L, Lu LM, Li HL, Sun M, Liu B, Chen M, Niu YT, Ye JF, et al. 2016. Three of life for the genera of Chinese vascular plants. J Syst Evol 54 (4): 277-306. DOI: 10.1111/jse.12219.

Christensen AC. 2013. Plant mitochondrial genome evolution can be explained by DNA repair mechanisms. Genome Biol Evol 5 (6) 1079-1086. DOI: 10.1093/gbe/evt069.

Darracq A, Varre JS, Drouard LM, Courseaux A, Castric V, Laprade PS, Oztas S, Lenoble P, Barbe B, Touzet P. 2011. Structural and content diversity of mitochondrial genome in beet: A comparative genomic analysis. Genome Biol Evol 3: 723-736. DOI: 10.1093/gbe/evr042.

Dye MJ, Proudfoot NJ. 2001. Multiple transcript cleavage precedes polymerase release in termination by RNA polymerase II. Cell 105 (5): 669-681. DOI: 10.1016/S0092-8674(01)00372-5.

Duminil J, Pomonge MH, Petit RJ. 2002. A set of 35 consensus primer pairs amplifying genes and introns of plant mitochondrial DNA. Mol Ecol Notes 2 (4): 428-430. DOI :10.1046/j.1471-8286.2002.00263.x.

Eksomtramage T, Duangpan S. 2018. Genetic variation of improved oil palm tenera hybrid populations using morphological and SSR markers. Songklanakarin J Sci Technol 40 (6): 1329-1335. DOI: 10.14456/sjst-psu.2018.163.

Geneaid. 2012. Genomic DNA mini kit (plant) protocol http://www.geneaid.com/sites/default/files/GP9.

Genievskaya Y, Abugalieva S, Zhubanysheva A, Turuspekov Y. 2017. Morphological description and DNA barcoding study of sand rice (Agriophyllum squarrosum, Chenopodiaceae) collected in Kazakhstan. BMC Plant Biol 17 (1): 177-185. DOI: 10.1186/s12870017-1132-1.

Gorissen SHM, Crombag JJR, Senden JMG, Waterval WAH, Bierau J, Verdijk LB, Loon LJCV. 2018. Protein content and amino acid composition of commercially available plant-based protein isolates. Amino Acids 50 (12): 1685-1695. DOI: 10.1007/s00726-018-2640-5.

Green P, Ewing B, Miller W, Thomas PJ, Green ED. 2003. Transcriptionassociated mutational asymmetry in mammalian evolution. Nat Genet 33: 514-517. DOI: $10.1038 / n g 1103$.

Harnelly E, Thomy Z, Fathiya N. 2018. Phylogenetic analysis of Dipterocarpaceae in Ketambe Research Station, Gunung Leuser National Park (Sumatra, Indonesia) based on rbcL and matK genes. Biodiversitas 19 (3): 1074-1080. DOI: 10.13057/biodiv/d190340.

Hollingsworth PM, Graham SW, Little DP. 2011. Choosing and using a plant DNA barcode. PLoS One 6 (5): e19254. DOI: 10.1371/journal.pone.0019254.
Jo BS, Choi SS. 2015. Introns: The functional benefits of introns in genomes. Genomics Inform 13 (4): 112-118. DOI: 10.5808/GI.2015.13.4.112.

Kar P, Goyal A, Sen A. 2015. Maturase K gene in plant DNA barcoding and phylogenetics. Lambert Academic Publishing, Saarbruken.

Kaye FJ, Kratzke RA, Gerster JL, Horowitz JM. 1990. A single amino acid substitution results in a retinoblastoma protein defective in phosphorylation and oncoprotein binding. Proc Natl Acad Sci USA 87 (17): 6922-6926. DOI: 10.1073/pnas.87.17.6922.

Kitazaki K, Kubo T. 2010. Cost of having the largest mitochondrial genome: Evolutionary mechanism of plant mitochondrial genome. J Bot 2010: 620137. DOI: 10.1155/2010/620137.

Kuzmina ML, Johnson KL, Barron HR, Herbert PDN. 2012. Identification of vascular plants of Churchill, Manitoba, using a DNA barcode library. BMC Ecol 12: 25. DOI: 10.1186/1472-6785-12-25.

McCullough AJ, Schuler MA. 1997. Intronic and exonic sequences modulate $5^{\prime}$ splice site selection in plant nuclei. Nucleic Acids Res 25 (5): 1071-1077. DOI: 10.1093/nar/25.5.1071.

Morgulis A, Coulouris G, Raytselis Y, Madden TL, Agarwala R, Schäffer AA. 2008. Database indexing for production MegaBLAST Searches. Bioinformatics 24: 1757-1764. DOI: 10.1093/bioinformatics/btn322.

Morley SA, Nielsen BL. 2017. Plant mitochondrial DNA. Front Biosci 22: 1023-1032. DOI: $10.2741 / 4531$

Mower JP, Tauzet P, Gummow J, Delph LF, Palmer JD. 2007. Extensive variation in synonymous substitution rates in mitochondrial genes of seed plants. BMC Evol Biol 7: 135. DOI: 10.1186/1471-2148-7-135.

Pervaiz T, Sun X, Zhang Y, Tao R, Zhang J. 2015. Association between chloroplast and mitochondrial DNA sequences in Chinese Prunus genotypes (Prunus persica, Prunus domestica, and Prunus avium). BMC Plant Biol 15: 4. DOI: 10.1186/s12870-014-0402-4.

Petit RJ, Duminil J, Fineschi S, Hampe A, Salvini D, Vendramin GG. 2005. Comparative organization of chloroplast, mitochondrial, and nuclear diversity in plant populations. Mol Ecol 14 (3): 689-701. DOI: $10.1111 / j .1365-294 X .2004 .02410 . x$

Provan J, Soranzo N, Wilson NJ, Goldstein DB, Powel W. 1999. A low mutation rate for chloroplast microsatellites. Genetics 153 (2): 943947. DOI: $10.1093 /$ genetics/153.2.943.

Riyanto R, Widodo I, Abbas B. 2018. Morphology, growth and genetic variations of sago palm (Metroxylon sagu) seedlings derived from seeds. Biodiversitas 19 (2): 602-608. DOI: 10.13057/biodiv/d190241.

Saddhe AA, Jamdade AR, Kumar K. 2016. Assessment of mangroves from Goa, West Coast India using DNA barcode. SpringerPlus 5 (1): 1554-1564. DOI: 10.1186/s40064-016-3191-4.

Savolainen V, Corbaz R, Moncousin C, Spchiger R, Manen JF. 1995. Chloroplast DNA variation and parentage analysis in 55 apples. Theor Appl Genet 90: 1138-1141. DOI: 10.1007/BF00222934.

Selvaraj D, Sarma RK, Sathishkumar R. 2008. Phylogenetic analysis of chloroplast matK gene from Zingiberaceae for plant DNA barcoding. Bioinformation 3 (1): 24-27. DOI: 10.6026/97320630003024.

Singh J, Banerjee S. 2018. Utility of DNA barcoding tools for conservation and molecular identification of intraspecies of rice genotypes belonging to Chhattisgarh using $\mathrm{rbcL}$ and matK gene sequences. Plant Arch 18: 69-75.

Smith DR. 2015. Mutation rates in plastid genomes: they are lower than you might think. Genome Biol Evo 7 (5): 1227-1234. DOI: 10.1093/gbe/evv069.

Tamura K, Nei M, Kumar S. 2004. Prospects for inferring very large phylogenies by using the neighbor-joining method. Proc Natl Acad Sci USA 101: 11030-11035. DOI: 10.1073/pnas.0404206101.

Tamura K, Stecher G, Kumar S. 2021. MEGA 11: Molecular evolutionary genetics analysis version 11. Mol Biol Evol 38: 3022-3027. DOI: 10.1093/molbev/msab120.

Viard F, El-Kassaby YA, Ritland A. 2001. Diversity and genetic structure in populations of Pseudotsuga menziesii (Pinaceae) at chloroplast microsatellite loci. Genome 44 (3): 336-344

Wulandari EF, Mawikere NL, Abbas B. 2021. Morphology and genetic diversity of sago palm accessions (Metroxylon sagu Rottb.) based on matK gene marker. J Cassowary 4 (1): 68-86 DOI: 10.30862/casssowary.cs.v5.i1.93 [Indonesian].

Yamamoto Y. 2011. State of the art sago research in Asia Pacific. Proceeding of the 10th International Sago Symposium. Bogor, Indonesia, 29-30 October 2011

Yater T, Tubur HW, Meliala C, Abbas B. 2019. Short Communication: A comparative study of phenotypes and starch production in sago palm (Metroxylon sagu) growing naturally in temporarily inundated and 
non-inundated areas of South Sorong, Indonesia. Biodiversitas 20 (4): 1121-1126. DOI: 10.13057/biodiv/d200425.

Zebua LI, Gunaedi T, Budi IM, Lunga N. 2019. The DNA barcode of red fruit pandan (Pandanaceae) cultivar from Wamena, Papua Province,
Indonesia based on matK gene. Biodiversitas 20 (11): 3405-3412. DOI: $10.13057 /$ biodiv/d201138.

Zhang Z, Schwartz S, Wagner L, Miller W. 2000. A greedy algorithm for aligning DNA sequences. J Comput Biol 20007 (1-2): 203-214. DOI: $10.1089 / 10665270050081478$ 